\title{
Can factitious disorder reach delusional level? A case study
}

\author{
„Czy zaburzenie pozorowane może osiągać poziom urojeniowości? Studium przypadku”
}

\section{Rafał Dubiel ${ }^{1}$ B, E, F, Adam Perzyński ${ }^{2}$ A, B, D-F, Ida Kłębukowska ${ }^{1}$, Aneta Perzyńska-Starkiewicz ${ }^{2}$, Iwona Chmiel-Perzyńska ${ }^{3}$ E,F, Marcin Olajossy ${ }^{2} \mathrm{~A}$}

1. University Hospital No 1, Lublin, Poland, II Department of Psychiatry and Psychiatry Rehabilitation

2. Medical University, Lublin, Poland, II Department of Psychiatry and Psychiatry Rehabilitation

3. Medical University, Lublin, Poland, Department of Experimental and Clinical Pharmacology

\begin{abstract}
The paper describes a patient, who has been consulted and hospitalized multiple times, due to dermatological lesions on his face. We will present his medical history and describe circumstances leading to the final diagnosis of factitious disorder. In the theoretical part we will try to answer the question, whether the extreme severity of the factitious disorders can, at some point, reach the level of delusions.
\end{abstract}

Keywords: factitious disorder, delusions

\section{Introduction}

Münchausen syndrome consists in feigning the symptoms of the disease in order to receive help or hospitalization [1]. The name of this disorder originates from Richard Asher, who in 1951 described the cases of patients who were regularly appearing in hospitals with a variety of symptoms. The described phenomenon derives its name from the book „Baron Munchausen's Narrative of his Marvelous Travels and Campaigns in Russia" written by Rudolf Erich Raspe and based on the biography of Karl Friedrich Hieronymus Freiherr von Münchhausen. Münchhausen who lived in the 18th century, was a soldier-aristocrat, famous for telling the unusual, imaginary wartime stories . He stated for example that he had been flying on a cannonball, or had visited the Moon. As the Baron was widely respected, no one called him a liar, people rather found his stories amusing and witty. Furthermore, he never malingered symptoms of any disease.

Nowadays, the name is being replaced by „factitious disorder", which in the international classificationof diseases (ICD 10) is encoded as (F)68. 1. Due to the lack of proper registration of such cases, the statistics considering factitious disorder are based upon case studies described in medical literature. The prevalence rate for this disorder is estimated at $0.6-3 \%$ of all hospitalized patients [2-4] and at $0.02-0.9 \%$ among patients of specialized clinics [5-8].Factitious disorder is most commonly found in endocrinology, cardiology, and dermatology. Yates and Feldman's analysis suggests that Münchhausen syndrome occurs much more frequently among women, who represent $66.2 \%$ of all cases [9].The severity varies. FD is rarely fatal and death of the patient is rather accidental than self-inflicted [10-13]. Half of the described cases of malingering concerns people somehow related to medical professions and that is why, it is so easy for them to feign the symptoms and that they are so hard to detect [9].It is expected that in the context of the development of the Internet and the accessibility of information and knowledge - especially when it comes to highly specialized medical domains, this percentage will rise. Technological changes also result in the appearance of two specific forms of FD nowadays described in the literature Münchhausen by the Internet and Münchhausen by Google[14]. The first term refers to patients who introduce themselves as ill or as caregivers of sick people via the Internet or social media in order to gain emotional support, compassion or attention. The second term refers to those people who seek medical documentation including medical imagining, in order to copy them and use as proof of their illness. Another form of the disorder is called Münchhausen by proxy, where a person fakes or causes syndromes in another person who usually stays under their care - such as child or elderly, for example. Factitious disorder is sometimes combined with other mental disorders. Most often depression (41. 8\%), personality disorders (16.5\%) and anxiety disor$\operatorname{ders}(15.3 \%)$ are diagnosed first [9].

\section{Case description}

At the time of the admission to the Second Clinic of Psychiatry and Psychiatric Rehabilitation the patient was 
51 years old, single and had no children. He had higher education, and was working in one of the state archives. In his youth, he had been involved in the political opposition activities rooting against Communist Party. Following that, he had been arrested and repressed. After 1989, he focused on working for the benefit of other repressed people. He was engaged in politics a lot and was representing radical nationalist views, which he was spreading via local newspapers he published himself and via his internet blog. The issue of confiscated property engaged him the most, as he himself was living in pre-wartime tenement house. Due to his exhortations to racial hatred and insults towards Jewish nation, he was put under trial. It was widely broadcasted by media. The patient was then offered support from various radical associations. Some publicists even called him a "brave fighter for the freedom of speech". His trial lasted 7 years and ultimately in view of minor social harmfulness of his acts, he was released. Despite this, the patient's social functioning begun to deteriorate. While he was still under the trial, his mother passed away and at that time the patient started complaining about his skin condition on face. This took place approximately 7 years before his first psychiatric hospitalization. From this moment on, he had been consulted multiple times, and 6 years later, after many difficulties in reaching the right diagnosis, he was finally admitted to Dermatology Clinic. Multiple tests were made, but the diagnosis of primary skin disease was not confirmed as the patient was diagnosed with bacterial infection of wounds, which suggested psychological origins of his condition.

Later a psychiatrist consulted him, as dermatologists suspected that he was intentionally manipulating around his face and scratching his skin in order to feel sick.

Psychiatrists, however, found no signs of mental disorder and did not order pharmacological treatment. During that hospitalization, doctors were able to treat skin scratches and lesions on the patient's face. Abdominal USG in which hydronephrosis of right kidney was found, was also performed. A short period of conservative treatment was ordered, followed by nephrectomy due to lack of excretion functions.

Being discharged from Dermatology Clinic, the patient continued diagnosing his skin abnormalities in another hospital at Internal Medicine ward. The presence of systemic connective tissue or immunological disease was not confirmed, but the patient refused to accept the diagnosis and pursued the search for the disease. He was also consulting the results of ANA antibodies tests (1:80) even though the doctors reassured him about the absence of illness.

In 2015 after being persuaded by extended family, the patient first visited a psychiatrist. This took place at the end of the trial, and after his kidney removal. However, he chose not to start the recommended treatment as he was convinced he did not need one. He was also unable to name any of previously prescribed medications and did not go to psychologist either. Meanwhile many of his friends were concerned about the changes in patient's behavior. After the cancellation of the trial, they visited him and noticed deep scratches at his face and neck. Emergency was called as they were afraid that the patient could be dangerous to himself. At that day, he was feeling upset, and agreed to be admitted to Psychiatric Ward."They told me that I was depressed and called an ambulance"- he stated later. Around that time, he started to isolate and withdraw himself from social activities, claiming that this had happened because of the skin abnormalities on his face. Meanwhile, the patient's social functioning began to deteriorate approximately 2 years earlier when his mother- with whom he was living- had died from breast cancer.He became almost delusional, saying that his skin was falling apart due to leprosy, claimed that deeper tissues were also covered with the disease. The patient did not accept the arguments that no skin disease was to be found and that all laboratory results were normal. He even was convinced that his aesophagus was covered with blisters. As the use of antipsychotics treatment was introduced (Olanzapinae $10 \mathrm{mg} /$ day , Zuclopentixol 50mg/day) he became not only less delusional, but also his skin condition begun to improve. He was diagnosed with delusional disorders and discharged at request of his friends, so that he could continue the treatment at the university facility.

At the moment of admission to the Second Clinic of Psychiatry and Psychiatric Rehabilitation, the patient's mood and drive were lowered. He was spending most of the time in bed and showed no concern for his appearance and hygiene. Antipsychotic treatment was continued with gradual reduction of prescribed doses. During this hospitalization, no new skin lesions were to be found, while the old ones disappeared completely.

The patient however sustained his belief that the disease has marred his face, even after being convinced that there was no serious skin or organ changes. As he begun reporting problems with his eyesight, urgent ophthalmologist consultation was called. No organic pathology was found, and since the patient was confronted with this consult, he reported no more problems with sharpness of vision.

During the patient's stay at the Clinic, psychological assessment was conducted, with results stated below:

Neuropsychological tests are normal and do not indicate the existence of organic changes in central nervous system(Mini Mental State Examination - 29 points, Clock Drawing Test-normal, Graham-Kendall's Test of Remembering the geometric forms -3 points, Subscales of the Set of Tests to Study Cognitive Processes in Patients with 
Brain Damage by Łucki: classification, picture absurdities, proverbs, metaphors, memory, visual agnosia - standard The patterns of abstract thinking are correct. No interferences in the cognitive functioning were found. The ability to focus attention was not disrupted.

Operative memory and motor-visual coordination are developed correctly. The cause-and- effect thinking abilities are at the same and normal level as analytic and systemic abilities.

Results of the searching for the severity of depression scales, point to the existence of depression with mild severity of symptoms (Beck's Depression Inventory- 25 points, Hamilton Depression Inventory- 14 points), Test PHQ-9 (Patient Health Questionaire)- 12 points. The areas of feelings, social relations and of somatic reactions are equally disturbed. In the area of affection, the patient shows sadness, pessimism, depression, anxiety. He attributes to himself a lot of flaws and weaknesses, does not like himself and has a strong sense of hopelessness and emptiness.

In the area of social relations irritability, a sense of isolation from others, lowered interest in contacts with people are to be found. The patient has difficulties in making decisions and solving problems. He is sensitive to the reactions of other people, which causes avoidance in creating closer emotional relations and a social distance.The sphere of feelings influences his social functioning. Lack of faith in himself, pessimistic perception of the world and his future are holding him back from the active participation in social life. The area of somatic reactions is also disrupted. The patient wakes up very early in the morning with no possibility of further falling asleep and complaints about fatigue and difficulty in performing daily duties.

Results of projecting tests point to the lack of life goals, lack of purpose in life, no future perspectives and a sense of inability to cope in difficult situations.

(Purpose In Life Test by Crumbough and Micholik, Sacks and Sidney Test).

The patient reports the need to be healthy and fit, while he feels that it is never going to happen. It is difficult for him to make decisions about his future life. He rarely reflects on his life and sees no solution to many difficult situations.

He rejects any difficult and problematic situations and tries not to seek any solutions. He claims that many situations are beyond him, he is also poorly adapted psychologically. The patient is pessimistic, has poor psychological adaptation and troubles in coping with difficult situations. He is also poorly resistant to stress and is unable to adapt to the requirements of daily life ".

\section{Discussion}

Establishing the accurate diagnosis of Munchausen syndrome is often very difficult, takes place too late and does not always result in finding the accurate treatment. A high possibility of recurrence and resistance to treatment has been observed among the patients [16]. This leads to more medical interventions and causes suffering to both caregivers and patients. The destructive effect of FD on medical staff can be found, as it causes anger and irritation and reduces the motivation to help $[17,18]$.The costs of hospitalization, unnecessary tests and treatment are estimated to be from 200,000 to 1 million dollars per patient, therefore early detection not only results in avoiding deterioration of one's health, but can also lead to significant saving in costs $[19,20]$.

After the exclusion of somatic causes of the illness and diagnosing FD, the differential diagnosis between somatoform disorder and malingering should occur. Despite some minor similarities, simulating symptoms are different when it comes to the underlying motives. We assume that patents with FD have unconscious motives and that the essence of the disorder lies in one's desire to play the role of a patient, while in case of malingering the purpose is either material gain or avoidance of criminal liabilities [21].

Somatoform disorder is characterized by the presence of complaints of somatic symptoms and insistence on further diagnostic tests, despite negative results of those previously conducted ones or despite doctors' explanations about the lack of illness. Even if any medical condition is to be found, the patient's symptoms do not correspond to the severity of the disease. They are rather the causes of distress and are engaging most of patient's attention and activity [22]. The difference between FD and somatoform disorder is lack of objective disease symptoms ant the fact that the essence of disorder is mainly emotional.

Malingering patients are convinced of having a somatic disease and they tend to exaggerate minor symptoms. The difference between malingering and FD is that, when it comes to malingering, neither real symptoms nor activity causing them is present [23].

FD should be differentiated with somatoform delusions, which are characterized by the lack of existing disease symptoms that could respond to patient claims. Similar to somatoform disorder or malingering, the root of the problem lies in the thinking area and it is not possible to convince the patient that his beliefs may be false [24].

In the presented case study, skin lesions were present but the patient did not want to get any compensation, exemption from criminal liability or avoidance of the trial. His symptoms however, undoubtedly helped improving his social relations. His friends not only called the ambulance, but also intervened with doctors in order to assure him the best medical care. They showed attention and interest in him. 
Another social context was also presented in a view this case should be looked into. The patient was distinctly different from his friends from the times of opposition, who were able to obtain well-paid occupations and good material status. They could also adapt to the new, postcommunist reality, while the patient continued his oppositionist activities and was given no help from former coactivists. They actually cut back their support as his political activity- broadcasted by the media- began more and more controversial. Scratches on patient's face were noticeable and drew attention of others - including his friends, who then sought help and tried to provide him best medical care. Adapting the role of the diseased not only provided the patient with support but also helped explaining difficulties in his everyday functioning and justified his failures.The build-up of dermatological symptoms was strongly connected to deterioration of patient's social life. Psychological assessment showed that he had low capacity of coping and tendency to withdraw himself from existing problems. Such features hindered or prevented him from solving ongoing difficulties.

It is also possible to hypothesize that skin lesions were inflicted automatically and that the patient was not aware of the process. Similar mechanism is present in trichotillomania [25]. In this case, two different models of behavior are distinguished - active- when a patient pulls his hair out consciously, for example in front of the mirror and automatic, the nature of which is manipulatory restlessness. We should assume that skin damages in the presented case, were inflicted automatically as a symptom of anxiety and psychological tension and that they were not conscious. In that case - FD could not be diagnosed, as the criteria of the lack of deliberate action could not be met. As he had been living and working alone and spent most of the time isolated, inability to get more information about the patient's behavior from other people, hinders from full case review. Given the social context and the fact that patient acquired social support through his illness, final diagnosis of FD was stated.

A prolonged state of tension and anxiety combined with the presence of skin wounds, enabled the patient to lose insight, as his assessment of the situation became delusional. At some point, he refused to acknowledge proof of lack of the disease from dermatologists and following tests and hospitalizations could not help him obtain the insight. Furthermore, the patient did not take into consideration the fact, that there was significant improvement after the antipsychotic treatment had been introduced. Later on, he was reluctant to follow doctors' orders. The underlying cause of development of delusions in this case, seems to be not the endogenous but situational factor, which was reinforced by several circum- stances. The first one is the patient's schizothyme personality. The second one being the patient's experience as political oppositionist during his youth helped him establish the belief that the nature of the world is rather threatening. The longstanding trial should be perceived as another burdensome issue, as the very first complaints about skin changes, appeared shortly after it (the trial) had started. As his legal situation became more complicated, the complaints and help seeking also became more severe. Further worsening happened after the death of his mother, while the trial was still ongoing. Finally, the severity of the disorder reached the level of delusions.

Delusions or psychotic states are commonly associated with endogenous disorder. In the available literature, we did not find the answer for the question given in the title of this study. FD is a disorder caused by specific circumstances, but it is not the only case, where uncomfortable situation leads to the psychosis.

This is not the only situation when psychosis is the result of complicated and unpleasant situation. Cases of "Prison psychosis" have been described in which symptoms were clearly psychotic, but their origins were situational. Those are currently perceived as psychotic states and in ICD10 coded as dissociative disorders.By the term dissociative disorder, we understand inadequate and nonspecific unconscious reactions to traumatic situations or disrupted relations. The disintegration occurs between conscious control of one's behavior and memory, identity, perception or movement, "Conversion" is often used interchangeably to dissociation. The term itself explains psychogenic nature of the disorder, as it can be explained as a transformation of tension and anxiety into non-specific and odd symptoms. A person receives benefits in the form of withdrawal of painful contents from the thinking area, while emotions are taking new, often symbolic somatic form. Seeking attention and improvement of one's situation can be perceived as secondary benefit. Symptoms of conversion last from an hour to months. Factors involved in extending that time, are interpersonal in nature, as the change of patient's situation leads to the reductions of symptoms. It should be stressed that delaying psychiatric intervention reduces the effectiveness of treatment.

Prison psychosis also called The Ganser Syndrome ", puerilism, pseudo-dementia, "Wild Man Syndrome" is most commonly described among conversion disorders found in inmates [26]. Some authors [27] also described formation of delusionsof innocence, release from punishment or of pardon. Worsening of reactive psychosis with delusions and hallucinations may require psychiatric treatment and even lead to the death [26]. Szymusik and Telesiński described a case in which the persistence of the 
delusions and the development of psychopathological equivalent of schizophreniaoccurred, although the authors do not exclude the possibility of theconvergence between the time of imprisonment and the development of the disease.

Another type of psychotic disorder that bases on situational grounds is induced delusional disorder which, in the ICD-10 is encoded within the psychotic disorders (F24). Induced psychosis develops when healthy person adapts disease symptoms from other psychotic person. This occurs in cases of high-closeness of these people and the type of strong isolation from the corrective information coming from the outside world.Person inducing the symptoms is usually the authority and dominates over the other person intellectually and emotionally [28].

The induced state wears off as people get separated and the information about health is given. Although cases have been presented where separation did not cause the symptoms of the disease do wear off, but we are not sure whether the described patients had not been sick independently. In one of the very rare subtypes of induced psychosis - folie induite - delusional contents are taken over from one sick patient on another- also sick patient [28,29].

Another disorder in the development of which the functioning of the family system is crucial is anorexia. In cases of this disorder, especially when it comes to longlasting episode, the beliefs in abnormal body weight could take form of delusions [30].

\section{Wstęp}

Praca dotyczy pacjenta, który w ostatnich latach był kilkukrotnie konsultowany i hospitalizowany $\mathrm{z}$ powodu zmian dermatologicznych. Przedstawimy jego historię oraz okoliczności prowadzące do postawienia końcowej diagnozy zaburzenia pozorowanego. W części teoretycznej postaramy się odpowiedzieć na pytanie czy skrajne nasilenie zaburzenia pozorowanego może osiągnąć poziom urojeń.

Zespół Münchhausena polega na wywoływaniu objawów choroby w celu otrzymania pomocy lub hospitalizacji [1]. Nazwę zawdzięczamy Richardowi Asherowi, który w 1951 roku opisał przypadki pacjentów regularnie pojawiających się w szpitalach z rozmaitymi dolegliwościami.

Nazwę dla opisanego zjawiska zaczerpnął z powieści „Niezwykłe przygody Barona Münchhausena" Rudolfa Ericha Raspego, wzorowanej na życiorysie Karla Friedricha Hieronymusa Freiherr von Münchhausena. Münchausen żyjący w XVIII w. żołnierz-arystokrata prócz bogatego życiorysu, słynął z niezwykłych, zmyślonych opowieści m.in. o tym jak leciał na kuli armatniej, odwiedził księżyc czy wyciągnął się z bagna pociągając za paski naszyte na

\section{Summary}

In Psychiatry, similarly to the attempts to systematize all of the living world, sharp boundaries cannot be distinguished. When we analyze the nature of mental activity, we try to separate the differences between the manifestations of its proper and pathological activity. This division itself is not always sharp, and for example, there are many difficulties with stating the difference between delusions from beliefs [31].

Within the area of psychopathological symptoms, there are not sharp boundaries either. In the literature, it is being stressed that the symptoms may have different severity and it is accompanied by variable degree of insight. The lack of sharp boundaries and existence of spectrums of disorder, indicates most often the OCD, dysmorphophobia, somatoform disorder, anorexia [32].

This is why many authors [23,24,30,32, 33] stress the need to perceive the individual symptoms and syndromes in terms of a broader spectrums rather than separated nosological diagnoses.

Described disorders show variability of symptoms. The common feature is the background situation and their severity, which can reach a psychotic nature. It could not be unambiguously stated that those disorders developing in response to the difficult situation are purely neurotic. Therefore, it has to be assumed that, just as is true for other disorders, the factitious disorder may also take the form of delusions.

cholewkach swoich butów. Baron był powszechnie szanowany, nie zarzucano mu kłamstwa, wiedząc że niewiarygodne opisy "dokonań" utrzymywał raczej w konwencji żartu. Baron tym bardziej nigdy nie pozorował objawów chorobowych.

Obecnie nazwa wypierana jest przez określenie zaburzenie pozorowane ( ang. factitious disorder), które w Międzynarodowej Klasyfikacji Chorób (ICD 10) jest kodowane jako F68.1.

Statystyki schorzenia ze względu na brak rejestracji takich przypadków opierają się na analizie dostępnych w literaturze opisów przypadków. Częstość występowania jest szacowana na 0,6-3\% wszystkich pacjentów hospitalizowanych [2-4], 0,02-0,9\% wśród pacjentów specjalistycznych klinik [5-8]. Analizy Yatesa oraz Feldmana wskazują, że dziedzinami których najczęściej dotyczy problem zaburzeń pozorowanych to endokrynologia, kardiologia, dermatologia, oraz że zespół Münchhausena występuje znacznie częściej u kobiet, które stanowią 66,2\% wszystkich przypadków [9].

Nasilenie bywa różne. Rzadko kończy się śmiercią pacjenta, jest to raczej efekt przypadku niż celu [10-13] 
W połowie opisanych przypadków pozorujący są lub byli związani z zawodami medycznymi, co ułatwia im działanie oraz zmniejsza szanse wykrycia [9]. Należy się spodziewać, że w związku z rozwojem Internetu i powszechności dostępu do informacji, także wysoko specjalistycznych dziedzin, odsetek ten będzie się zmniejszał. Zmiany technologiczne spowodowały też pojawienie się dwóch szczególnych postaci zaburzenia pozorowanego opisywanych w literaturze - Münchhausen by Internet oraz Münchhausen by Google [14]. Pierwsze pojęcie odnosi się do pacjentów niezgodnie z prawdą przedstawia się jako osoby chore, lub opiekujące się chorym członkiem rodziny na forach internetowych lub serwisach społecznościowych w celu uzyskania emocjonalnego wsparcia, współczucia bądź uwagi ze strony innych internautów. Drugie pojęcie - Münchhausen by Google - odnosi się do osób szukających w Internecie cudzej dokumentacji medycznej, w tym badań obrazowych w celu skopiowania i używania ich jako „dowodu” własnej choroby. Kolejną szczególną postacią zaburzenia jest przeniesiony zespół Münchhausena ( Münchhausen by proxy), gdzie osoba pozoruje lub wywołuje występowanie objawów nie u siebie a u osób będących pod ich opieką, najczęściej u bliskich tj. dziecko, czy też osoby starsze.

Zaburzenie pozorowane bywa poprzedzone innymi zaburzeniami psychicznymi - najczęściej jako pierwsze rozpoznawano depresję $(41,8 \%)$, rzadziej zaburzenia osobowości $(16,5 \%)$ i zaburzenia lękowe $(15,3 \%)$ [9].

\section{Opis przypadku}

Pacjent w chwili przyjęcia do II Kliniki Psychiatrii i Rehabilitacji Psychiatrycznej 51-letni kawaler, bezdzietny. Wykształcenie wyższe, historyk, pracował w jednym z państwowych archiwów. W młodości zaangażowany w działalność opozycji niepodległościowej. W stanie wojennym internowany oraz represjonowany. Za swoją działalność otrzymał odznaczenie państwowe. Po 1989 roku prowadził działalność na rzecz osób represjonowanych. Nadal był aktywnie zaangażowany w politykę, prezentując radykalne poglądy na łamach wydawanych lokalnie czasopism narodowych oraz w ramach własnego bloga internetowego. Szczególnie zajmował go problem „mienia utraconego”, jako że sam zamieszkiwał przedwojenną kamienicę $w$ centrum miasta. Efektem kontrowersyjnych wypowiedzi było doniesienie do prokuratury o publicznym nawoływaniu do nienawiści i znieważanie osób narodowości żydowskiej. W tym czasie $\mathrm{z}$ różnych środowisk dochodziły do pacjenta liczne głosy wsparcia, zaś sam proces był relacjonowany przez niektóre media. Przez część publicystów był określany jako bohater prześladowany za poglądy i walczący o wolność słowa. Po siedmiu latach trwania procesu sąd uznał stopień winy za nieznaczny i warunkowo umorzył sprawę. Mimo wyja- śnienia sytuacji prawnej funkcjonowanie społeczne pacjenta zaczęło się w tym momencie pogarszać.

Równolegle z problemami prawnymi i sytuacją rodzinną (śmierć matki, brak innych relacji rodzinnych) pojawiły się ze strony pacjenta skargi na zmiany skórne Miało to miejsce na około 7 lat przed hospitalizacją psychiatryczną. Od tego czasu był wielokrotnie konsultowany ambulatoryjne aż wreszcie, po 6 latach trudności w postawieniu diagnozy i nieskuteczności leczenia został skierowany na oddział dermatologiczny. Pomimo licznych badań nie udało się postawić diagnozy pierwotnej choroby skóry, stwierdzono jedynie nadkażenie bakteryjne ran twarzy, co nasunęło przypuszczenie psychicznego podłoża zgłaszanych problemów i zaowocowało konsultacją psychiatryczną pacjenta. Dermatolodzy podejrzewali, że pacjent sam dokonuje manipulacji i rozdrapuje skórę twarzy a potem jest przekonany o poważnej chorobie skórny. Konsultujący psychiatra nie stwierdził obecności choroby psychicznej i nie zalecił żadnego leczenia. W czasie hospitalizacji dermatologicznej uzyskano wygojenie nadżerek i ran skóry twarzy. W badaniu ultrasonograficznym jamy brzucha stwierdzono wodonercze nerki prawej. Po okresie zachowawczego leczenia nefrologicznego wykonano prawostronną nefrektomię $\mathrm{z}$ powodu utraty funkcji wydzielniczej.

Po wypisie pacjent kontynuował diagnostykę zmian skórnych w kolejnym szpitalu, na oddziale chorób wewnętrznych. Wykluczono tam istnienie układowej choroby tkanki łącznej oraz zaburzeń immunologicznych. Pacjent nie zgadzał się z tą diagnozą, był nieufny wobec lekarzy, wielokrotnie konsultował pozytywny wynik badania na obecność przeciwciał przeciwjądrowych (ANA) - 1:80 - mimo zapewnień, że takie miano nie daje podstaw rozpoznania choroby układowej.

Do psychiatry po raz pierwszy zgłosił się za namową dalszej rodziny w 2015 roku tj. pod koniec trwania procesu sądowego, już po usunięciu nerki. Zalecanego przez psychiatrę leczenia nie podjął, twierdząc, że go nie potrzebuje. Nie umiał podać nazw przepisanych leków. U psychologa nigdy nie był.

W tym okresie zaczął się izolować, nie miał ochoty na spotkania towarzyskie. Wiązał czasowo uszczuplenie kontaktów towarzyskich $\mathrm{z}$ pojawianiem się zmian skórnych. Funkcjonowanie społeczne wyraźnie zaczęło się pogarszać na około 2 lata przed hospitalizacją psychiatryczną. W tym czasie zmarła na raka piersi mieszkająca z pacjentem matka. Liczni znajomi z czasów działalności w opozycji byli zaniepokojeni zmianą zachowania pacjenta. Po umorzeniu procesu sądowego odwiedzając go zauważyli głębokie zadrapania na twarzy i wezwali zespół Pogotowia Ratunkowego obawiając się, że może zagrażać swojemu zdrowiu „kolega stwierdził, że mam depresję i zadzwonił po karetkę". Pacjent, mając tego 
dnia złe samopoczucie, zgodził się na hospitalizację psychiatryczną. Przy przyjęciu wypowiadał urojeniowe treści - był przekonany, że jego skóra się rozpada, przypomina trąd, twierdził, że głębiej położone tkanki także objęte są chorobą. Nie przyjmował argumentów w postaci braku objawów skórnych, ani negatywnych wyników badań dodatkowych. Był przekonany, że w przełyku występują pęcherze. Zastosowano leczenie przeciwpsychotyczne (olanzapina do $10 \mathrm{mg} /$ dobę, zuclopentixol do $50 \mathrm{mg} /$ dobę) po którym pacjent nie tylko zaprzestał wypowiadania treści urojeniowych, a stan skóry poprawił się. Na prośbę przyjaciół został wypisany z dotychczasowej placówki z diagnozą zab. urojeniowych F22.0 i zgłosił się do placówki medycznej ośrodka uniwersyteckiego w celu kontynuowania leczenia.

W czasie pobytu pacjent był mało aktywny, w obniżonym nastroju i napędzie, zalegał w łóżku, nie wykazywał dbałości o wygląd i higienę. Kontynuowano leczenie przeciwpsychotyczne stopniowo zmniejszając dawkę leków. Podczas hospitalizacji nie pojawiły się nowe zmiany skórne a dotychczasowe ustąpiły w całości. Pacjent podtrzymywał przekonanie, że choroba zeszpeciła mu twarz, choć nie podtrzymywał przekonania o istniejącej poważnej chorobie skórnej, ani istnienia zmian narządowych. Chory zaczął jednak zgłaszać problemy $\mathrm{z}$ widzeniem. Pilnie wykonana konsultacja okulistyczna nie wykazała organicznej patologii. Po konfrontacji z wynikiem oceny okulistycznej chory przestał zgłaszać problemy z ostrością widzenia.

W trakcie hospitalizacji dokonano oceny psychologicznej, której wyniki zamieszczamy poniżej.

„Wyniki testów neuropsychologicznych mieszczą się w normie i nie wskazują na istnienie zmian organicznych w ośrodkowym układzie nerwowym (Mini Mental State Examination - 29 pkt, Test Rysowania Zegara - norma, Test Pamięci Form Geometrycznych Graham-Kendall 3 pkt - norma, Test L. Bender - 58 pkt - norma, Podskale z Zestawu Prób do badania procesów poznawczych u pacjentów z uszkodzeniem mózgu Łuckiego: klasyfikacja, nonsensy obrazkowe, przysłowia, metafory, pamięć, gnozja wzrokowa - norma).

Prawidłowo przebiegają procesy myślenia abstrakcyjnego. Nie stwierdza się zakłóceń w funkcjonowaniu poznawczym. Niezaburzona jest koncentracja uwagi. Prawidłowo rozwinięta jest pamięć operacyjna oraz koordynacja wzrokowo -ruchowa. Na dobrym poziomie rozwinięte jest myślenie przyczynowo-skutkowe i zdolności analityczno-syntetyczne.

Wyniki skal badających nasilenie objawów depresyjnych wskazują na depresję o umiarkowanym nasileniu (Skala Depresji Becka - 25 pkt, Skala Depresji Hamiltona - 14 pkt.,

Test PHQ-9 (Patient Health Questionaire) [15]- 12 pkt., Inwentarz objawów depresyjnych Becka i Pichota).
Jednakowo zaburzone są sfera uczuciowości, stosunków społecznych jak i reakcji somatycznych.

W sferze uczuciowości badany wykazuje smutek, pesymizm, przygnębienie, lęk. Przypisuje sobie wiele wad i uchybień, nie lubi siebie, ma poczucie beznadziejności i pustki. W sferze stosunków społecznych pojawia się drażliwość i izolacja od innych, mniejsze zainteresowania kontaktami z ludźmi. Badany przejawia trudności w podejmowaniu decyzji oraz w rozwiązywaniu problemów. Jest wrażliwy na reakcje innych ludzi, co powoduje unikanie wchodzenia w bliższe związki emocjonalne oraz trzymanie ludzi na dystans. Na kontakty społeczne rzutuje sfera uczuciowości. Ciągły brak wiary w siebie, pesymistyczna wizja świata oraz własnej przyszłości nie pozwalają na aktywne uczestniczenie w życiu społecznym. Zaburzona jest również sfera reakcji somatycznych. Badany wybudza się bardzo wcześnie bez możliwości ponownego zaśnięcia, zgłasza skargi na męczliwość i trudności w wykonywaniu codziennych obowiązków.

Wyniki testów projekcyjnych, wskazują na brak celów życiowych. brak poczucia sensu życia, brak perspektyw na przyszłość, poczucie niemożności poradzenia sobie w trudnych sytuacjach ( Skala Skala Sensu Życia Purpose in Life Test Crumbougha i Micholik'a, Test Uzupełniania Zdań Sacks'a i Sidneya). Badany zgłasza potrzebę bycia zdrowym i sprawnym, z jednoczesnym poczuciem że nigdy to nie nastąpi. Trudno mu podjąć decyzje co do przyszłego życia. Badany rzadko zastanawia się nad swoim życiem, nie widzi wyjścia z wielu trudnych sytuacji. Sprawy trudne, problematyczne odsuwa od siebie. Nie próbuje szukać rozwiązania. Wiele sytuacji go przerasta, jest słabo przystosowany psychologicznie.

Badanego cechuje pesymizm, jest słabo przystosowany psychologicznie, ma trudności w radzeniu sobie w sytuacjach trudnych, mało odporny na stres. Nie potrafi przystosować się do wymagań życia codziennego."

Ostatecznie dokonano analizy przebiegu zaburzenia i postawiono diagnozę zaburzenia pozorowanego.

\section{Dyskusja}

Postawienie trafnej diagnozy w przypadku zespołu Münchhausena jest często trudne, opóźnione i nie zawsze skutkuje prawidłowym leczeniem. Obserwuje się opór ze strony pacjentów oraz dużą nawrotowość, która pociąga za sobą koszt kolejnych interwencji medycznych oraz cierpienie zarówno opiekunów jak i samych chorych [16]. Podobnie destrukcyjny efekt wywiera zaburzenie pozorowane na personelu medycznym - powoduje demotywację, żal, złość $[17,18]$.

Koszty dla systemu ochrony zdrowia - pobytu, zbędnych badań i leczenia - są szacowane na od 200000 do miliona dolarów w przeliczeniu na jednego pacjenta $[19,20]$. Wczesne wykrycie zaburzenia pozorowanego 
skutkuje więc nie tylko uchronieniem pacjenta przed potencjalnym pogorszeniem stanu zdrowia, ale także oszczędzeniem środków.

Po wykluczeniu podłoża somatycznego stwierdzanych objawów chorobowych i stwierdzeniu zaburzenia pozorowanego należy je różnicować z zaburzeniami występującymi pod postacią somatyczną (ang. somatoform disorders), zaburzeniem hipochondrycznym a także symulacją (ang. malingering). Symulacja mimo powierzchownych podobieństw różni się odmiennym motywem wytwarzania objawów. Przyjmujemy, że o ile w przypadku zaburzenia pozorowanego motywy są przez pacjenta nieuświadomione, a zasadniczą cechą jest pragnienie wejścia w rolę chorego i przyjęcia towarzyszącego jej wsparcia emocjonalnego, o tyle w przypadku symulacji działanie jest celowe, świadome i służy osiągnięciu konkretnego celu np. uzyskaniu korzyści materialnych, bądź uniknięciu odpowiedzialności karnej [21]. Zaburzenie somatyzacyjne charakteryzuje się obecnością skarg na objawy somatyczne i domaganiem się kolejnych badań pomimo negatywnych wyników tych wcześniej przeprowadzonych oraz tłumaczenia lekarzy o braku schorzenia. Nawet w przypadku realnie istniejących schorzeń zgłaszane przez chorego objawy nie odpowiadają chorobie po względem charakteru i nasilenia, za to wywołują poczucie dystresu i nadmiernie angażują uwagę i aktywność pacjenta [22]. Od zaburzenia pozorowanego zaburzenie somatyzacyjne różni się przede wszystkim brakiem obiektywnych objawów chorobowych a istota tego zaburzenia ma charakter głównie emocjonalny. W zaburzeniu hipochondrycznym pacjent jest przekonany o chorowaniu na chorobę somatyczną i odczytuje fizjologiczne lub nieznaczące objawy jako wyraźne dowody na istnienie schorzenia. Od zaburzenia pozorowanego różni się brakiem realnych objawów chorobowych i brakiem aktywności powodującej powstawanie objawów [23].

Zaburzenie pozorowane należy również różnicować z urojeniami hipochondrycznymi. Urojenia charakteryzują się brakiem realnie istniejących objawów chorobowych, które swoim charakterem lub nasileniem odpowiadałyby zgłaszanych skargom. Podobnie jak w przypadku zaburzenia somatyzacyjnego, czy hipochondrycznego problem dotyczy sfery myślenia, przy czym w urojeniach nie istnieje możliwość przekonania pacjenta o nieprawdziwości jego przekonań. [24].

W omawianym przypadku istniały wyraźne zmiany skórne, jednak pacjent chciał w ten sposób uzyskać odszkodowania, zwolnienia z odpowiedzialności karnej czy możliwości unikania stawiania się na rozprawy sądowe. Objawy niewątpliwie wpłynęły korzystnie na relacje społeczne - zainteresowanie, wręcz troska kolegów, którzy niezależnie od siebie wzywali karetkę pogotowia, interweniowali u lekarzy w celu zapewnienia mu najlep- szej możliwej opieki i warunków, pomagali w zmianie oddziału szpitalnego. Istniał również inny kontekst społeczny, w którym można rozpatrywać opisywany przypadek. Otóż wszyscy koledzy i przyjaciele z młodości, $\mathrm{z}$ którymi był zaangażowany $\mathrm{w}$ działalność opozycyjną potrafili uzyskać dobrą pozycję zawodową i materialną, założyli własne rodziny. Pod tym względem wyraźnie od nich odstawał. Podczas gdy koledzy dobrze radzili sobie $\mathrm{w}$ warunkach postkomunistycznych, tak on kontynuował działalność pro patriotyczną $\mathrm{w}$ formie bloga internetowego. W swojej działalności nie uzyskiwał już wsparcia od dawnych opozycjonistów. Ponieważ była to działalność budząca kontrowersje, a do tego była nagłośniona przez media, koledzy wyraźnie odcinali się w wyrażaniu oficjalnego i nieoficjalnego wsparcia w tym zakresie. Zmiany na skórze twarzy były dobrze widoczne i musiały przyciągać uwagę innych, w tym kolegów. To sprawiło, że zaangażowali się w pomoc i interweniowali, by zapewnić mu opiekę lekarską. Przyjęcie roli chorego nie tylko zapewniło choremu wsparcie, ale także wyjaśniało trudności w funkcjonowaniu, czy też usprawiedliwiało poniesione porażki życiowe. Narastanie objawów dermatologicznych miało związek z komplikowaniem się sytuacji życiowej pacjenta. Ocena psychologiczna wykazała, że pacjent cechował się niskimi zdolnościami radzenia sobie, tendencją do odsuwania od siebie problemów - takie cechy utrudniały lub uniemożliwiały rozwiązanie bieżących trudności.

Można również rozważyć hipotezę, że uszkodzenia skóry były dokonywane w sposób automatyczny, nieświadomy, czego pacjent nie rejestrował. Podobny mechanizm jest obecny w trichotillomanii [25]. W przypadku tego zaburzenia wyróżnia się dwa modele behawioralne: aktywny, polegający na świadomym wyrywaniu włosów np. przed lustrem oraz automatyczny, nawykowy, który ma charakter niepokoju manipulacyjnego. Można więc przyjąć hipotezę, że do uszkodzeń skórnych dochodziło w sposób automatyczny i aktywność ta była przejawem niepokoju, napięcia psychicznego i nie była rejestrowana w świadomości. Wówczas nie można by zdiagnozować zaburzenia pozorowanego, gdyż niespełnione jest kryterium celowego działania. Elementem utrudniającym pełną ocenę był brak możliwości uzyskania danych co do zachowania pacjenta od innych osób. Mieszkał sam a odizolowane stanowisko pracy sprawiało, że nie spotykał ludzi przez znaczną część dnia. Biorąc pod uwagę kontekst społeczny i uzyskane dzięki temu przez pacjenta wsparcie przyjęto diagnozę zaburzenia pozorowanego. Przedłużający się stan napięcia i niepokoju i obecność ran skóry sprawiły, że pacjent stracił wgląd $\mathrm{w}$ chorobę a ocena sytuacji przyjęła charakter urojeniowy. Na tym etapie pacjent nie przyjmował już żadnych dowodów od lekarzy dermatologów, kolejne badania, porady i hospitalizacja na oddziale dermatologicznym nie przyniosły efektu 
w postaci uzyskania wglądu. Pacjent nie uwzględniał też faktu, że poprawa nastąpiła pod wpływem leczenia przeciwpsychotycznego a nie dermatologicznego, a dalej niechętnie stosował się do zaleceń lekarskich.

W opisanym przypadku podłożem rozwoju urojeń zdaje się nie być czynnik „endogenny” ale sytuacyjny, który został wzmocniony przez kilka uwarunkowań. Pierwszym $\mathrm{z}$ nich jest schizotymiczna osobowość pacjenta. Jako drugi czynnik należy uznać wieloletnie doświadczenia opozycyjne w okresie dorastania i młodości, które budowały przekonanie o zagrażającym charakterze świata. Kolejnym elementem przewlekle obciążającym psychicznie był kilkuletni proces sądowy. Pierwsze skargi na zmiany skórne pojawiły się w rok po rozpoczęciu procesu sądowego. Komplikowanie się sytuacji prawnej było odzwierciedlone $\mathrm{w}$ nasileniu zgłaszanych zmian skórnych i prób ich leczenia. Nawet po wyroku, który pacjent starał się interpretować na swoją korzyść, nadal obawiał się rewizji wyroku, apelacji poszkodowanych i dalszego procesu. Kolejne zaostrzenie zmian skórnych nastąpiło po śmierci matki, jeszcze $\mathrm{w}$ trakcie trwania procesu.

Ostatecznie nasilenie zaburzeń osiągnęło poziom urojeń.

Najczęściej urojenia czy stan psychotyczny kojarzy się lekarzom z chorobą „endogenną”. W literaturze nie udało się znaleźć odpowiedzi na pytanie postawione w tytule pracy. Zaburzenie pozorowane jest uwarunkowane sytuacyjnie, jednak nie jest to jedyny przypadek, w którym efektem niekorzystnej sytuacji jest psychoza. Od dawna opisywano „psychozy więzienne”, które ewidentnie miały charakter psychotyczny a uwarunkowane były jedynie sytuacyjnie. Obecnie nie są postrzegane jako stany psychotyczne. W ICD-10 są kodowane w dziale zaburzeń nerwicowych jako zaburzenia dysocjacyjne. Zaburzenia dysocjacyjne są nieadekwatną, niespecyficzną reakcją na niekorzystną sytuację, traumatycznym wydarzeniem, czy zaburzonymi relacjami i przyjmują charakter nieświadomy i niecelowy. Dochodzi tu do dysocjacji czyli do dezintegracji pomiędzy świadomą kontrolą zachowań a pamięcią, tożsamością, percepcją czy motoryką. Wyróżnia się tu amnezję dysocjacyjną, fugę dysocjacyjną, stupor dysocjacyjny, trans i opętanie, dysocjacyjne zaburzenia czucia i ruchu, zespół Gansera, osobowość mnogą. Terminem stosowanym często zamiennie dla dysocjacji jest konwersja.

Już sama nazwa tłumaczy psychogenny, sytuacyjny charakter zaburzeń. Konwersja to przemiana napięcia, niepokoju, lęku w niespecyficzne, zupełnie inne objawy. Osoba uzyskuje korzyść w postaci wyeliminowania bolesnej treści $\mathrm{z}$ myślenia a emocje przyjmują nowy, często symboliczny charakter somatyczny. Wtórną korzyścią jest uzyskanie uwagi otoczenia, i zmiana sytuacji na korzystniejszą np. zwolnienie z obciążających zadań, funkcji itp. Objawy konwersyjne mogą trwać od godziny po wiele miesięcy. Wskazuje się, że czynnikami przedłużającymi obecność objawów jest charakter interpersonalny trudności pacjenta oraz nierozwiązywalność jego problemów. Zmiana sytuacji na korzystną dla pacjenta prowadzi do ustąpienia objawów. Podkreśla się, że odwlekanie interwencji psychiatrycznej o 1-2 lata powoduje jej niską skuteczność.

„Psychozy więziennej” tj. zespół Ganser’a, puerylizm, pseudodemencja, „zespół dzikiego człowieka”, zespół błazeński są najczęściej opisywanymi zaburzeniami reaktywnymi, które stwierdzano u oskarżonych czy osadzonych [26]. Niektórzy autorzy [27] opisywali również powstawanie urojeń niewinności, uwolnienia od kary i ułaskawienia. Nasilenie psychoz reaktywnych z występowaniem $\mathrm{w}$ ich przebiegu urojeń i omamów wymagać może leczenia psychiatrycznego a nawet prowadzić do śmierci [26]. Szymusik i Telesiński opisują przypadek, w którym prawdopodobnie doszło do utrwalenia urojeń i rozwoju obrazu psychopatologicznego odpowiadającego schizofrenii, choć autorzy nie wykluczają, że mogło dojść do zbieżności czasowej pomiędzy osadzeniem a rozwojem choroby.

Innym rodzajem zaburzenia o charakterze psychotycznym o podłożu sytuacyjnym jest indukowane zaburzenie urojeniowe, które w ICD-10 jest kodowane w obrębie zaburzeń psychotycznych (F24). Psychoza udzielona (indukowana) rozwija się $\mathrm{w}$ przypadku przyjęcia przez osobę zdrową objawów od innej, psychotycznej osoby, jako objawów prawdziwych. Do takiej sytuacji dochodzi w przypadkach dużej bliskości tych osób oraz swoistej izolacji od korygujących informacji z otoczenia. Osoba indukująca zwykle jest autorytetem dla zaindukowanej, dominuje nad nią intelektualnie i emocjonalnie [28]. Stan psychozy indukowanej ustępuje pod wpływem rozdzielenia osób i przekazania osobie pierwotnie zdrowej informacji o prawdziwej sytuacji. Opisywano wprawdzie przypadki, gdy rozdzielenie nie powodowało ustąpienia objawów choroby ale nie ma pewności czy nie miano wówczas do czynienia $\mathrm{z}$ dwoma osobami chorującymi niezależnie. W jednym z bardzo rzadkich podtypów „obłędu udzielonego", określanego jako folie induite dochodzi do przejęcia treści urojeniowych przez osobę chorą od innej chorej osoby [28-29].

Zaburzeniem, w rozwoju którego kluczowe znaczenie ma zwykle funkcjonowanie systemu rodzinnego, jest anoreksja psychiczna. W przypadkach tego zaburzenia, zwłaszcza o długotrwałym przebiegu, może dochodzić do przemiany przekonań o nieprawidłowej masie ciała w urojenia [30].

\section{Podsumowanie}

W psychiatrii, podobnie jak w przypadku prób usystematyzowania całego świata ożywionego, nie można wytyczyć ostrych granic. Analizując fenomenologię 
aktywności psychicznej próbujemy oddzielać przejawy jej prawidłowej aktywności od patologicznej. Już ten podział nie zawsze jest ostry i można mieć trudność w oddzieleniu np. przekonań od urojeń [31]. W obrębie objawów psychopatologicznych również nie ma ostrych granic. W literaturze podkreśla się, że dany objaw może mieć różne nasilenie i towarzyszy mu wówczas różnego stopnia wgląd. Na brak ostrych granic i istnieniu raczej spektrów zaburzeń najczęściej wskazuje się w przypadku zaburzenia obsesyjno-kompulsyjnego, zaburzenia hipochondrycznego, dysmorfofobii, anoreksji [32]. Dlatego liczni autorzy [23, 24, 30, 32, 33] podkreślają konieczność postrzegania poszczególnych objawów i zespołów w ujęciu spektrów a nie osobnych jednostek nozologicznych.

Przytoczone powyżej zaburzenia ukazują ich dużą różnorodność pod względem objawów. Ich wspólną cechą jest podłoże sytuacyjne oraz nasilenie, które może osiągać charakter psychotyczny. Nie można więc jednoznacznie stwierdzić, że zaburzenia, rozwijające się $\mathrm{w}$ reakcji na trudną sytuację mają charakter czysto nerwicowy. Dlatego należy przyjąć, że, podobnie jak przypadku innych zaburzeń, zaburzenie pozorowane $\mathrm{z}$ czasem może przybrać formę urojeń.

\section{Conflict of interest}

The authors have declared no conflict of interest.

\section{References:}

1. DSM-5 American Psychiatric Association. Diagnostic and Statistical Manual of Mental Disorders. Arlington: American Psychiatric Publishing; 2013.

2. Fliege H, Scholler G, RoseM,Willenberg H, Klapp BF. Factitious disorders and pathological self-harm in a hospital population: an interdisciplinary challenge. Gen Hosp Psychiatry 2002;24(3):164-71.

3. Kapfhammer HP, Rothenhäusler HB, Dietrich E, Dobmeier P, Mayer C. Artifactual disorders-between deception and selfmutilation. Experiences in consultation psychiatry at a university clinic. Der Nervenarzt 1998;69(5):401-9.

4. Sutherland AJ, Rodin GM. Factitious disorders in a general hospital setting: clinical features and a review of the literature. Psychosomatics 1990;31(4):392-9.

5. Ballas SK. Factitious sickle cell acute painful episodes: a secondary type of Munchausen syndrome. Am J Hematol 1996;53(4):254-8.

6. Bauer M, Boegner F. Neurological syndromes in factitious disorder. J Nerv Ment Dis 1996;184(5):281-8.

7. Bhargava D, Al-Abri R, Rizvi SG, Al OkbiMH, Bhargava K, Al-Adawi S. Phenomenology and outcome of factitious disorders in otolaryngology clinic in Oman. Int J Psychiatry Med 2007;37(2):229-40.

8. Mailis-Gagnon A, Nicholson K, Blumberger D, ZurowskiM. Characteristics and period prevalence of self-induced disorder in patients referred to a pain clinic with the diagnosis of complex regional pain syndrome. Clin J Pain 2008;24(2):176-85.

9. Yates G., Feldman M. Facticious disorder: a systematic review of
455 cases in the proffesional literature. General Hospital Psychiatry 2016; 41, 20-28.

10. Hirayama Y, Sakamaki S, Tsuji Y, Sagawa T, Takayanagi N, Chiba H, et al. Fatality caused by self-bloodletting in a patient with factitious anemia. Int J Hematol 2003;78(2):146-8.

11. McEwen DR. Recognizing Munchausen's syndrome. J Assoc Perioper Regist Nurs 1998;67(2):440-2.

12. Nichols GR, Davis GJ, Corey TS. In the shadow of the baron: sudden death due to Munchausen syndrome. Am J Emerg Med 1990;8(3):216-9.

13. Vaduganathan M, McCullough SA, Fraser TN, Stern TA. Death due to Munchausen syndrome: a case of idiopathic recurrent right ventricular failure and a review of the literature. Psychosomatics 2014;6(55):668-672.

14. Feldman MD (July 2000):: Munchausen by Internet: detecting factitious illness and crisis on the Internet. South. Med. J. 93 (7): 669-72.

15. Tomaszewski K., Zarychta M., Bieńkowska A., Chmurowicz E., Nowak W., Skalska A.: Walidacja polskiej wersji językowej Patient Health Questionnaire-9 w populacji hospitalizowanych osób starszych. Psychiatria Polska 2011, XLV, 2, 223-233

16. Feldman M.D., Eisendrath S.J.: The Spectrum of Factitious Disorders. Washington DC., American Psychiatric Press, 1996.

17. Crawford SM, Jeyasanger G,Wright M. A visitor with Munchausen's syndrome. Clin Med 2005;5(4):400-1.

18. Dahale AB, Hatti S, Thippeswamy H, Chaturvedi SK. Factitious disorder - experience at a neuropsychiatric center in southern India. Indian J Psychol Med 2014; 36(1):62.

19. Romano A, Alqahtani S, Griffith J, Koubeissi MZ. Factitious psychogenic nonepileptic paroxysmal episodes. Epilepsy Behav Case Rep 2014;2:184-5.

20. Bright R, Eisendrath S, Damon L. A case of factitious aplastic anemia. Int J Psychiatry Med 2001;31(4):433-41.

21. Rogers R., Jackson R. L., Kamiński P.L.: Factitious psychological disorders the overlooked response style in forenestic evaluations. Journal of Forenestic Psychology Practice. 2005, 5, 21-41.

22. Folks GD, Feldman MD, Ford CV: Somatoform disorders, factitious disorders, and malingering, in Psychiatric Care of the Medical Patient, 2nd ed. Edited by Stoudemire A, Fogel BS, Greenberg DB. Oxford, UK, Oxford University Press, 2000, pp 459-475

23. Hanssen DJ, Lucassen PL, Hilderink PH, Naarding P, Voshaar RC.: Health-Related Quality of Life in Older Persons with Medically Unexplained Symptoms. Am J Geriatr Psychiatry. 2016 Nov;24(11):1117-1127

24. Popovich UO.: Endogenous episodes of juvenile psychosis with hypochondriac delusions, Zh Nevrol Psikhiatr Im S S Korsakova. 2014;114(1 Pt 2):20-7

25. Wolski M, Gawłowska-Sawosz M, Gogolewski M, Wolańczyk T, Albrecht P, Kamiński A.: Trichotillomania, trichophagia, trichobezoar - summary of three cases. Endoscopic follow up scheme in trichotillomania. Psychiatr Pol. 2016;50(1):145-52.

26. Szymusik A., Teleśnicki S., Postępy Psychiatrii i Neurologii, 1997, 6, suplement 1(4), 9-15

27. Wachholz L. Psychopatologia sądowa. PZWL. Kraków 1923

28. Prochowicz K. Obłęd we dwoje. Objawy i psychospołeczne uwarunkowania indukowanych zaburzeń urojeniowych. Psychiatria Polska 2009, 18 (1): 19-30.

29. Dosiak M., Wojtyna E., Underman T., Bojarowski M. Indukowane zaburzenie urojeniowe. Postępy Psychiatrii i Neurologii 2005; 14 (supl. 1/20): 30-32.

30. Steinglass JE, Eisen JL, Attia E, Mayer L, Walsh BT.: Is anorexia nervosa a delusional disorder? An assessment of eating beliefs in anorexia nervosa. J Psychiatr Pract. 2007 Mar;13(2):65-71. 
31. Sass L., Byrom G.: Phenomenological and neurocognitive perspectives on delusions: A critical overview. World Psychiatry. 2015 Jun;14(2):164-73

32. Phillips KA, Kim JM, Hudson JI. Body image disturbance in body dysmorphic disorder and eating disorders. Obsessions or delusions? Psychiatr Clin North Am. 1995 Jun;18(2):317-34.

33. Dell'Osso L., Abelli M., Carpita B., Pini S., Castellini G., Carmassi C., and Ricca V.: Historical evolution of the concept of anorexia nervosa and relationships with orthorexia nervosa, autism, and obsessive-compulsive spectrum. Neuropsychiatr Dis Treat. 2016; 12: $1651-1660$.

\section{Correspondence address}

Adam Perzyński, M.D., Ph.D.

II Department of Psychiatry and Psychiatry Rehabilitation,

Medical University in Lublin

ul. Głuska 2, 20-439 Lublin

Tel. (+48) 81-744-09-67

Fax. (+48) 81-745-33-92

e-mail: adamperzynski@wp.pl

Otrzymano: 01.12.2016

Zrecenzowano: 06.12.2016, 10.12.2016

Przyjęto do druku: 12.12.2016 